\title{
A GOOGLE EARTH DATABASE OF CENTRAL AMERICAN VOLCANIC VENTS
}

\author{
UNA BASE DE DATOS DE GOOGLE EARTH DE FOCOS VOLCÁNICOS \\ CENTROAMERICANOS
}

\author{
Michael J. Carr \\ Department of Geological Sciences, Rutgers University, 610 Taylor Road, \\ Piscataway, New Jersey 08854-8066, USA \\ carrvolcano@gmail.com
}

(Recibido: 29/11/2016; aceptado: 14/03/2017)

\begin{abstract}
Satellite imagery in Google Earth reveals 807 volcanic vents for Central America. Most of these have already been recognized. In fact, previous catalogs include many volcanoes that are not obvious in Google Earth and they are not included here. Furthermore, 47 large but deeply eroded volcanoes are not included because they appear very old. On the other hand, many young vents may be obscured in areas of low quality imagery or in areas of dense cloud forest. High quality Google Earth coverage keeps expanding so this catalog can be improved with time. Lidar imagery would greatly improve vent detection. A significant problem with any list of volcanic features is determining the appropriate cutoff age. Topographic expression is the only available criterion for estimating age for most of the vents and this criterion is highly flawed because of differences in volcanic deposits, weathering, annual rainfall and other factors. Ideally, ${ }^{40} \mathrm{Ar} /{ }^{39} \mathrm{Ar}$ ages would be available for most of the volcanoes and the revealed space-time pattern of volcanic activity would allow improved hazard estimates as well as a deeper understanding of the causes and controls of volcanism. Instead, the database is a necessary step toward: a) recognizing important volcanological problems that can attract geochronological research funding and $b$ ) encouraging a long-term campaign for determining the temporal development of Central American volcanism. The database is intended as a draft to be used and improved, not a fixed list. Keywords: Volcanic vents, volcanic front, volcano types, Google Earth.
\end{abstract}

RESUMEN: Imágenes satelitales de Google Earth revelan la existencia 807 focos volcánicos en América Central. La mayoría de ellos ya habían sido reconocidos anteriormente. De hecho, catálogos anteriores incluyen muchos volcanes que no son evidentes en Google Earth y por tanto, no fueron incluidos aquí. Además, 47 grandes volcanes pero fuertemente erosionados no son incluidos debido a que aparentan ser muy antiguos. Por otro lado, muchos focos volcánicos pequeños pueden ser difíciles de observar en áreas donde las imágenes satelitales son de baja calidad o en áreas donde 
existen bosques nubosos muy densos. La cobertura de imágenes de alta calidad de Google Earth se sigue ampliando, así que este catálogo podrá mejorarse con el tiempo. Imágenes Lidar mejorarían grandemente la detección de focos volcánicos. Un problema significativo con cualquier catalogo de volcanes, es poder determinar la edad de corte apropiada. La expresión topográfica es el único criterio disponible para estimar la edad de la mayoría de los focos volcánicos y este criterio es muy deficiente debido a las diferencias en los depósitos volcánicos, erosión, grado de meteorización y otros factores. Idealmente, edades ${ }^{40} \mathrm{Ar} /{ }^{39} \mathrm{Ar}$ podrían estar disponibles para la mayoría de los volcanes y el patrón de espacio-tiempo revelado de la actividad volcánica permitiría una mayor comprensión del peligro volcánico, así como una comprensión más profunda de las causas y los controles del volcanismo. A su vez, esta base de datos es un paso necesario para poder realizar las siguientes tareas: a) reconocimiento de problemas vulcanológicos importantes que pueden atraer financiamiento para realizar proyectos de investigación enfocados en geocronología volcánica y b) alentar una campaña a largo plazo para determinar el desarrollo temporal del volcanismo en América Central. La base de datos presentada aquí está diseñada como un proyecto para ser utilizado y mejorado, no es una base de datos final.

Palabras clave: Focos volcánicos, frente volcánico, tipos de volcanes, Google Earth.

\section{INTRODUCTION}

Geographic information systems (GIS) provide a superior approach for maintaining geologic maps and data. Geospatial analysis allows comparison of digital and qualitative information to better understand many aspects of geology. Volcanic vents are an obvious category for GIS, especially if the data include qualitative and quantitative descriptions that allow analysis beyond the simple minimum information of latitude, longitude and name. Several catalogs of Central American volcanoes exist including Mooser, Meyer-Abich and McBirney (1958). Bohnenberger (1969), Alvarado (1989, 2000), Bemis et al. (2011) and the Smithsonian's catalog (http://volcano.si.edu/ list_volcano_holocene.cfm\#), as well as several papers and internal reports on specific vents or volcanic ranges The database presented here differs from previous efforts by using Google Earth (GE) as the primary filter through which to select volcanic vents.

A major difficulty in creating a catalog is deciding on an age or age proxy to truncate the list. The Catalog of Active Volcanoes of the World (e.g. Mooser, Meyer-Abich and McBirney, 1958) included only volcanoes with historic eruptions or solfataric activity. This criterion has the advantage of being clear but it ignored volcanoes that later demonstrated that they are not extinct, including Arenal volcano in Costa Rica that erupted in 1968, killing 78 people, and Pinatubo in the
Philippines that erupted cataclysmically in 1991. The Smithsonian Institution's Global Volcanism Program maintains an impressive list of volcanoes with Holocene activity. However, the start of the Holocene is based on the most recent retreat of continental glaciation. This event had a major impact on sea-level, which may have affected the activity rate of some island volcanoes. At high latitudes or high elevations glacial scars indicate pre Holocene activity, whereas a similar nearby volcano without glacial features is likely younger than about 11,000 years. For the most part however, de-glaciation was a sea-level event and not a volcanic event. For Central America the start of the Holocene is not an event that had any reported effect on volcanic activity. Recent Central American volcanoes have ages that range from 166 years for Cerro Negro in Nicaragua to about 600,000 years or more for the major volcanoes in central Costa Rica (e.g. Carr et al., 2007).

Using Google Earth images to identify the vents to include in a catalog does not solve the problem of establishing a uniform criterion for inclusion. Although many morphological characteristics of a 'young' volcano can be specified, there are pronounced differences in climate and land use across and along the volcanic regions that parallel the plate boundaries in Central America. In some areas with relatively arid climate, like southeastern Guatemala, quite old volcanoes appear minimally eroded and thus 'young' (Walker et al., 2011). 
Ideally, every monogenetic volcano and every geologic unit in a large volcanic center's stratigraphy would have a ${ }^{40} \mathrm{Ar} /{ }^{39} \mathrm{Ar}$ age determination or a radiocarbon age.

\section{DATA}

The catalogs of Mooser, Meyer-Abich and McBirney (1958), Bohnenberger (1969), Carr (1974) and Alvarado (2000) were combined and translated to a KML file. The volcanic regions were then systematically searched for vents not in the catalogs. Vent locations were then adjusted in GE. Seventyone previously recognized vents were moved to a tab labeled "Less Clear" because their GE images were not sufficiently distinctive as constructional volcanic landforms. Fortyseven vents that are clearly volcanic but much eroded and likely belonging to an earlier episode of volcanism were moved to a tab labeled "Older Vents." Because nearly all the area examined is volcanic, the relegation of many previously recognized vents was subjective. The goal was to include only those landforms that were unambiguously volcanic vents with primarily constructive morphology.

The Google Earth filtered data are in an Excel workbook and a kml file, both of which are available at: https://sites.google.com/site/ carrcentralamerica/home/volcanic-vents-incentral-america

In addition to the volcano catalogs mentioned above, many journal articles and maps were examined. Significant insights came from the works of Penfield, Rose and Halsor (1986), Williams, McBirney and Dengo (1964), Agostini et al. ( 2006), González, Torres and Birkle (1997), Williams and Meyer-Abich (1955), Sofield (2004), Weber, Wiesemann and Wittekindt (1974), Wiesemann (1975), Rapprich (2005), Rapprich et al. (2010), Rotolo and Castorina (1998), Hradecky (1997), Hradecky (2001), Hradecky et al. (1998), Hradecky et al. (2001), Alvarado et al. (2011). van Wyk de Vries, Grosse and Alvarado (2007) used Shuttle Radar Topography Mission (SRTM) data to obtain a synoptic view of Central American volcanism. This review is a very useful contrast to the Google Earth approached used here.
In areas of poor GE imagery the 1:50,000 scale topographic maps, available for most regions of Central America, were helpful.

Previous catalogs primarily focused on volcanoes and ignored minor parasitic vents and bocas of lava flows. These small features may provide useful information about the local stress field and were carefully looked for. Such minor vents are insignificant in terms of mass of eruptive products and they are transient because they can be buried by subsequent deposits. The history of vents during the 1961-2012 eruption of Pacaya volcano in Guatemala (Matías et al., 2012) clearly shows that the present surface of a composite cone reveals only a fraction of the total vent population.

The primary attraction of using GE is the ease with which large areas can be explored using a high speed internet connection. If the image quality is good it is possible to see volcanoes in remarkable detail and to zoom in and out to better evaluate the shape and size of volcanoes. Furthermore, the history of images in GE often provides superior views than the default image. The vertical exaggeration function helps clarify volcano shapes. Comparisons of different vents are almost effortless once a KML file of the database is read into Google Earth. Air photographs may provide superior images but are very cumbersome compared with the ease of virtually flying over the landscape in GE. Figure 1 is an example of the synoptic quality of the catalog. Each vent is given the same symbol and projected onto digital topography using GeoMapApp.

There are many downsides to using Google Earth to create a catalog. First, the topographic maps of Central America, especially the very useful 1:50,000 scale maps with a $1 \mathrm{~km}$ grid, are based on the NAD27 ellipsoid, whereas GE uses the WGS84 ellipsoid. The result is a shift where GE locations are about 100 to 200 m North of map locations. The latitude and longitudes provided here are from place-marks centered on vents and then saved into $\mathrm{kml}$ files that were then translated to text files. GE provides a Universal Transverse Mercator (UTM) grid which allows easy comparison to the topographic maps of Guatemala, Honduras and Nicaragua. The GE vent locations 


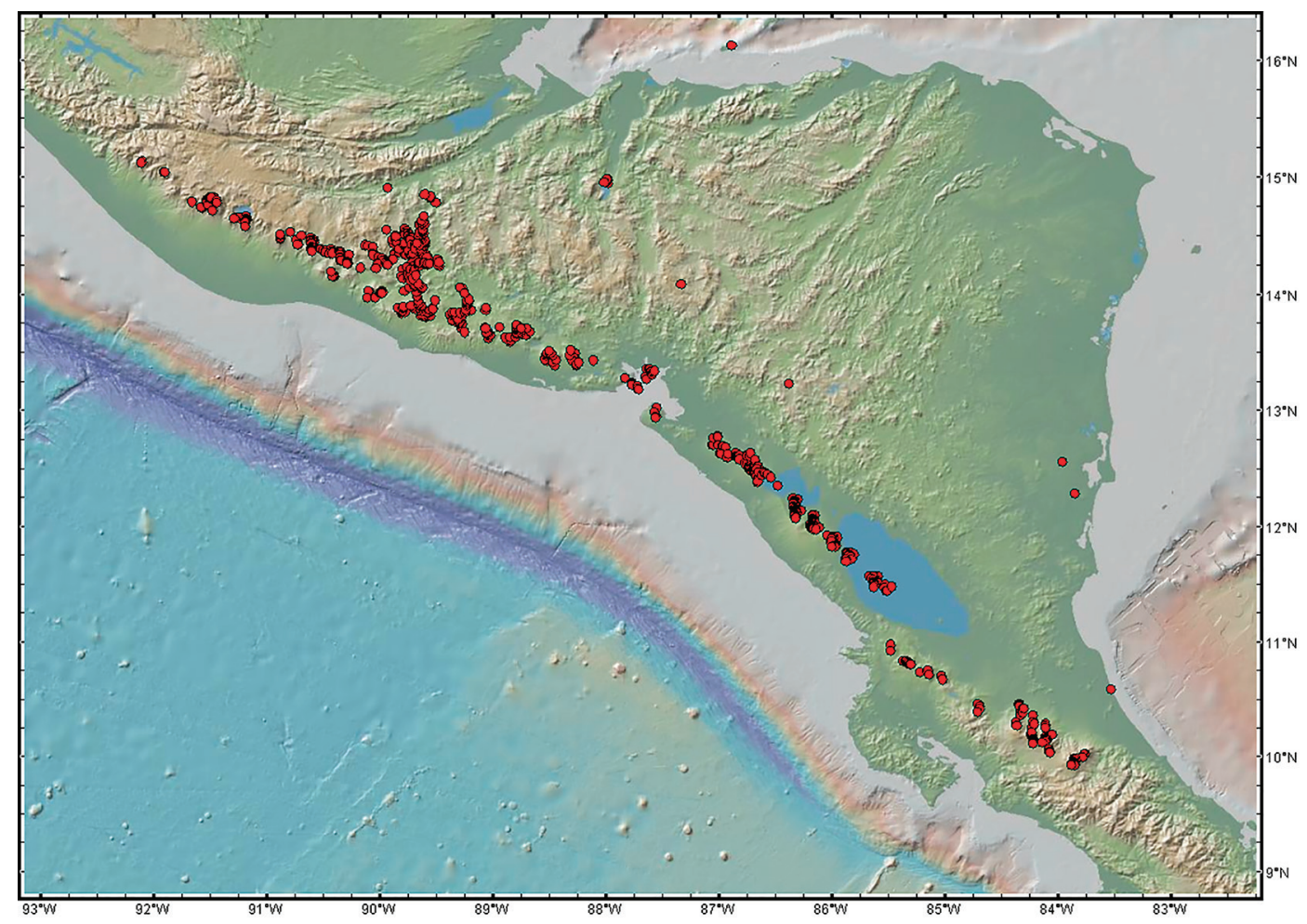

Fig. 1: Google Earth vent catalog for Central America in GeoMapApp.

are systematically north of the UTM locations on the topographic maps. For most practical purposes this shift is not important.

Satellite images bias the catalog in several ways. In arid regions there are typically several excellent images whose clarity is almost equal to that of air photographs. However, in areas of near constant cloud cover air photographs are usually superior because photographic missions can take advantage of brief breaks in the cloud cover. Dense forest hides small vents and forests are more common in areas of high cloud cover. The solution for these areas is Lidar (light detection and ranging). For example, Alvarado et al. (2011) used Lidar to better define maars on the north flank of Poás volcano in Costa Rica. Because the Caribbean slopes and eastern summits of most large Costa Rican volcanoes are poorly imaged in GE, topographic maps and the Alvarado (2000) catalog guided the selection of vents here.
The data set contains 12 columns which are described in the tab titled "Description." The column, Sample/Name, should be consistent with names from prior catalogs and I apologize for any inconsistencies. The additional small vents not in prior catalogs are given provisional names but formal names should be finalized by local geologists and geographers. The primary focus here was on longitude, latitude and kcode. The column called kcode is a first order attempt to classify the vents into meaningful groups or categories. There are 8 categories but three, composite cone, dome and caldera, each have an extra listing to denote the vents that have had historic activity. Twelve categories are too few but adding more becomes confusing because morphologies continuously vary. The worst failure of categorization is Masaya volcano, an active shield volcano that has erupted from several vents described as craters. The active craters are superficially like rather small composite 
Table 1

Descriptions of kcodes in database and symbols in Fig. 2.

\begin{tabular}{ccc}
\hline Code & Symbol & Description \\
\hline 7 & circle & composite volcano \\
8 & filled circle & $\begin{array}{c}\text { composite volcano, histori- } \\
\text { cally active } \\
\text { cinder cone }\end{array}$ \\
9 & cross & boca/small vent \\
10 & asterisk & maar/explosion vent \\
11 & star & dome \\
21 & hexagon & dome, historically active \\
22 & filled hexagon & caldera \\
25 & grey circle & caldera, historically active \\
26 & filled grey circle & shield \\
35 & pentagon & obsidian dome \\
36 & filled pentagon & \\
\hline
\end{tabular}

cones and so are categorized as composite cones, which is not accurate. Table 1 lists the categories and integer codes that result in specific symbols using Igpet software. Figure 2 plots the vents from central Guatemala to central El Salvador and displays each vent with its particular symbol.

The column labeled "Description" is primarily from previous catalogs and is roughly consistent with the categories in the kcode column. Because the 8 categories in kcode are too few to describe the continuous variation in volcanic morphology, the descriptions may provide a better understanding. However, the best method for understanding different vents is to use Google Earth to directly view them. Open the file, CAGEVents.KML, in GE and select the vent you wish to examine by Index number, the first column in the spreadsheet.

Along the volcanic front there are about 40 discrete centers or clusters of vents. Only a few volcanic centers, like Agua in Guatemala are simple cones. Most volcanic centers consist of combinations of composite cones, domes, fissure vents, caldera, maars, bocas and cinder cones. The column, labeled "Center" indicates which center a vent is in. The last column is the index number from the catalog of Guatemalan volcanoes of Bohnenberger (1969).
Several more columns could be added such as: age, volume, the cone parameters determined by Bemis et al. (2011) and numerous geochemical parameters. Several columns can be improved, especially description, elevation and height, the vertical extent of the volcanic edifice. Formal names should be added by local scientists. Future investigators can use this catalog as a convenient first pass on quantifying the physical and chemical characteristics of the numerous vents in Central America.

\section{RESULTS}

The GE database contains about 800 entries, considerably more than the 39 volcanic centers and four back-arc regions listed by Carr et al. (2003). The prior list sought to simplify the complex distribution of Central American volcanoes by emphasizing that relatively few discrete points (volcanic centers) account for most of the recent volcanic output from this plate margin. In contrast, the GE catalog seeks to locate all the vents that comprise recent volcanic activity in Central America regardless of size. This allows different questions to be posed.

Central American volcanoes occur primarily in two settings: first, a narrow volcanic front comprised of large volcanic centers; second, diffuse regions in the back-arc with many small volcanoes. The great majority of the back-arc volcanoes occur near extensional features in southeast Guatemala and western El Salvador. The extension is most obvious in the Ipala graben which extends roughly N-S. However, the GE catalog defines a wide triangular region between three back-arc volcanic fields, Cuilapa, Ipala and Apastapeque (Figure 2). Although there are N-S vent alignments in the Ipala region that parallel the prominent N-S faulting mapped by Williams, McBirney and Dengo (1964), northwesterly vent alignments are more obvious. Furthermore, there is a suggestion of a $\mathrm{N} 20 \mathrm{~W}$ vent alignment extending from the Apastateque region (Ap in Figure 2) to the center of the Ipala cluster.

The extensive back-arc volcanism shown in Figure 2 makes clear definition of the volcanic 


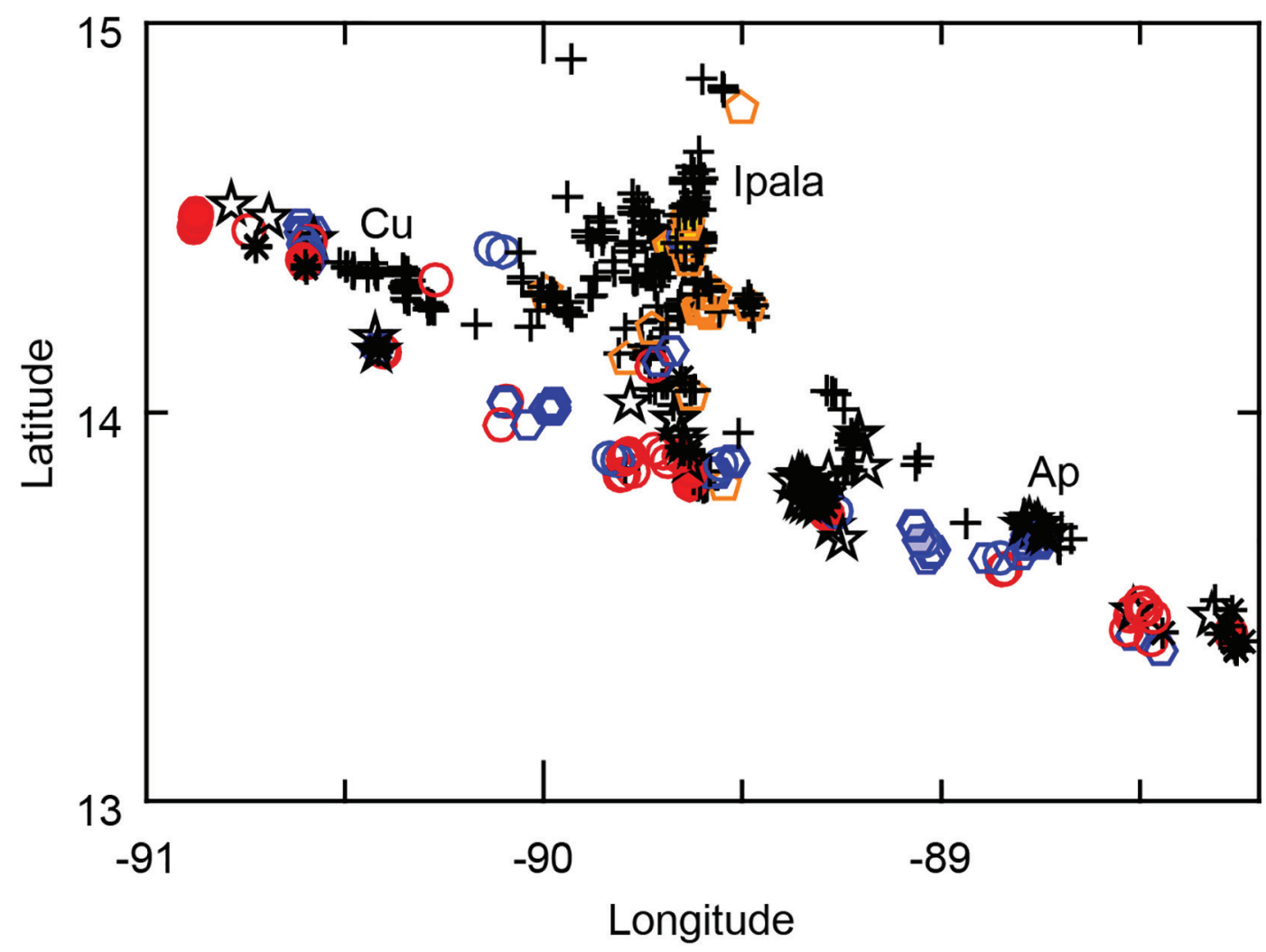

Fig. 2: Vent locations from central Guatemala to central El Salvador. See Table 1 for symbol key. Three labeled regions of back-arc volcanism are Cuilapa (Cu), Ipala and Apastepeque (Ap).

front difficult in that region. However, along the rest of the Pacific margin the volcanic front is well defined and its width, measured by the vent extent in the direction perpendicular to the plate margin, is quite variable. Figure 3 shows the variable width of the volcanic front along the margin using the right-stepping volcanic segments defined by several authors (e.g. Stoiber and Carr, 1973; Sapper, 1897; Dollfus and Montserrat, 1868). Widths vary from about $5 \mathrm{~km}$ to more than $20 \mathrm{~km}$. The cause for this rather large variation is not known.

\section{DISCUSSION}

The database of volcanic vents defined primarily from Goggle Earth images should not be considered a final, definitive list because new satellite images appear regularly. Eventually cloudy areas will get a clear image and additional vents will be seen. A further improvement will occur as Lidar images become available. Laser derived images greatly reduce the obscuring effects of thick vegetation and are superior to both satellite images and air photography for recognizing volcanic vents.

Selecting vents on the basis of constructive morphology is very subjective and so considerable improvement in the vent list (and our understanding of Central American volcanism) will occur if sufficient age-dating resources can be devoted to better defining the geologic history of Central American volcanoes. The vent catalog presented here may aid researchers seeking to make a strong case to funding agencies for resolving specific tectonic, geochemical and hazard evaluation problems. Joint tectonic and magmatic studies, like the excellent synthesis of Agostini et 

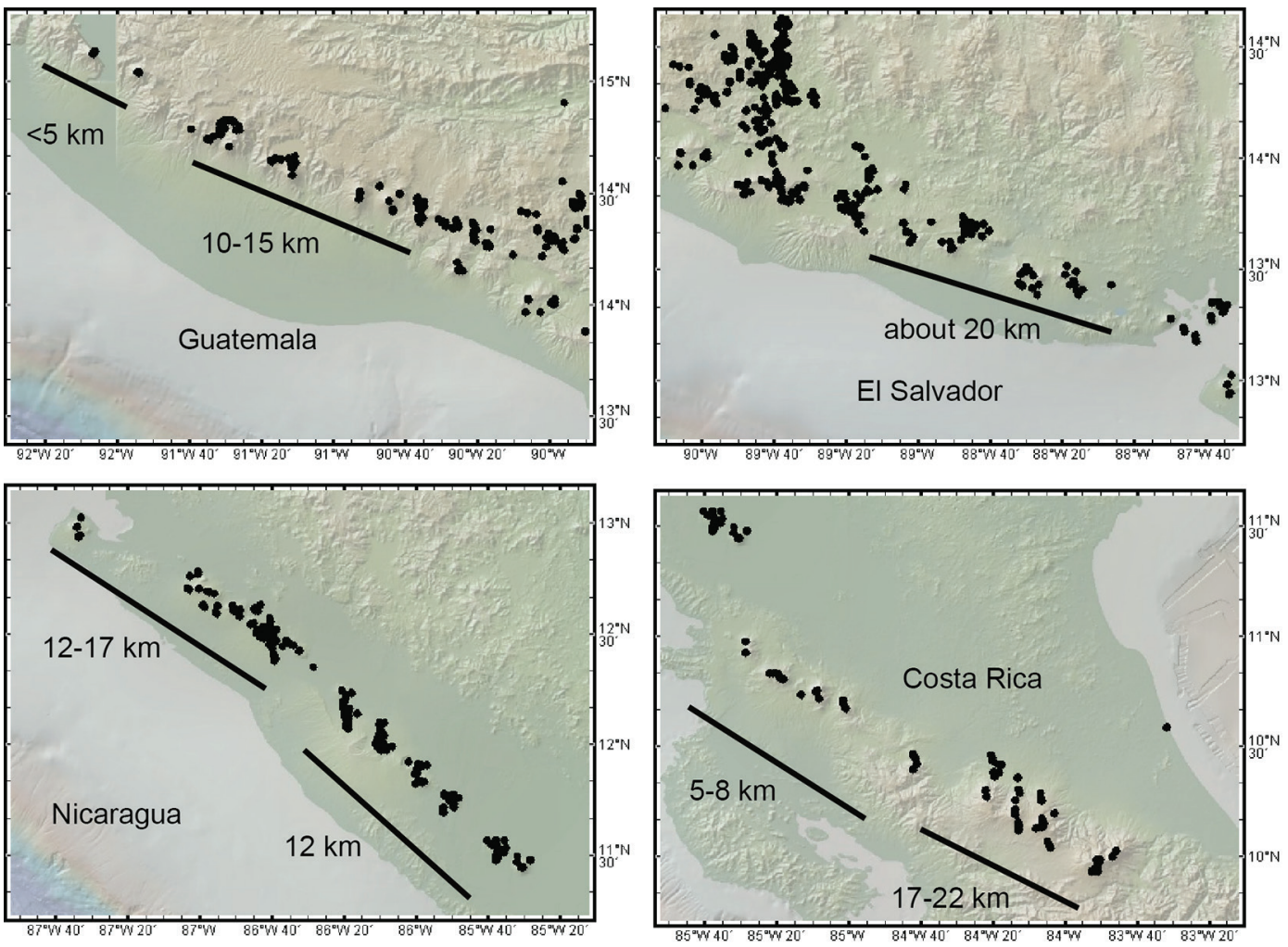

Fig. 3: Widths of the volcanic front for the volcanic segments in Central America. All maps are the same scale.

al. (2006), should find a convenient digital cata$\log$ of vents especially useful.

In creating the vent list one specific problem was immediately obvious in western Guatemala. Volcán Pecul is the youngest appearing volcano in the volcanic center about $10 \mathrm{~km} \mathrm{SE}$ from Santa María-Santiguito. There has been no historic activity at Pecul but the same could have been said about Santa María a few hundred years ago. Very little is known about this composite volcano with an obvious constructional morphology. At the very least there should be a hazard map and age determinations of the most recent activity.

\section{ACKNOWLEDGEMENTS}

Danielle Dondero taught me how to use Google Earth and made a draft GE catalog for El Salvador and Nicaragua as an Aresty Fellow.
William Rose and Guillermo Alvarado provided data, insights and useful criticisms. Pablo Ruiz also provided a helpful review.

\section{REFERENCES}

Agostini S., Corti, G., Doglioni, C., Carminati, E., Innocenti, F. and Tonarini, S. (2006). Tectonic and magmatic evolution of the active volcanic front in El Salvador: insight into the Berlin and Ahuachapán Geothermal Areas. Geothermics, 35, 368-408.

Alvarado, G. E. (1989): Volcanes de Costa Rica. San José: Euned.

Alvarado, G. E. (2000) (2 ed.): Volcanes de Costa Rica: Geología, historia y riqueza natural. San José: Euned. 
Alvarado, G. E., Soto, G. R., Salani, F. M., Ruiz, P. and Hurtado, L. (2011). The formation and evolution of Hule and Río Cuarto maars, Costa Rica. Journal of Volcanology and Geothermal Research, 201, 342-356. Doi 10.1016/j.jvolgeores.2010.12.017

Bemis, K., Walker, J. A., Borgia A., Turrin B., Neri, M., and Swisher III C. (2011). The growth and erosion of cinder cones in Guatemala and El Salvador: models and statistics. Journal of Volcanology and Geothermal Research, 201, 39-52.

Bohnenberger O. H. (1969). Los focos eruptivos cuaternarios de guatemala. Publicaciones Geológicas del Icaiti, 2, 23-24.

Carr M. J., Feigenson M. D., Patino L. C. and Walker J. A. (2003). Volcanism and geochemistry in central america: progress and problems. In J. Eiler and G. Abers (eds), Inside the subduction factory (pp. 153179). Geophysical monograph 138.

Carr, M. J., Saginor, I., Alvarado, G. E., Bolge, L. L., Lindsay. F. N., Milidakis, K., Turrin, B. D., Feigenson, M. D., and Swisher III., C. C. (2007). Element fluxes from the volcanic front of nicaragua and costa rica. Geochemistry, Geophysics, Geosystems (G3), 8, q06001. Doi: $10.1029 / 2006 \mathrm{gc001396}$

Dollfus A. and Montserrat. E. (1868). Voyage geologique dans les republiques de guatemala et de salvador: France, mission scientifique au Mexique at dans l'Amerique Centrale. Paris: Imprimerie imperiale.

González, E., Torres, V. and Birkle, P. (1997). Plio-Pleistocene volcanic history of the Ahuachapán Geothermal System, El Salvador: the Concepción de Ataco Caldera. Geothermics, 26, 555-575.
Hradecky, P. (1997). Estudio para el reconocimiento de la amenaza geológica en el área de Managua, Nicaragua. Managua: Servicio Geológico Checo, INETER.

Hradecky, P. (2001). Estudio geológico y reconocimiento de las amenazas geológicas en el volcán Apoyeque, Nicaragua. Managua: Servicio Geológico Checo, INETER.

Hradecky, P., Havlicek, P., Opletal, M., Rapprich, V., Sebesta, J., Sevcik, J. and Mayorga, E. (2001). Estudio geológico y reconocimiento de amenazas geológicas en el volcán Cosigüina, Nicaragua. Managua: Servicio Geológico Checo, INETER.

Hradecky, P., Micoch, B., Novak, Z., Sebesta, J. (1998). Estudio geológico y reconocimiento de riesgo natural y vulnerabilidad en el área de Masaya y Granada. Managua: Servicio Geológico Checo, INETER.

Matías, R. O., Rose W. I., Palma J. L., and Escobar-wolf, R. P. (2012). A 3d map of the 1961-2009 eruption of Volcán de Pacaya, Guatemala. Geological Society of America, Digital Maps and Charts Series, 10. Doi:10.1130/2012dmch010

Mooser, F., Meyer-Abich, H. and McBirney, A. R. (1958). Catalogue of the active volcanoes of the World, including solfatara fields: VI Central America. Rome: Iavcei.

Penfield, G. T., Rose, W. I. and Halsor, S. (1986). Geology of the Lake Atitlán volcanoes. Geological Society of America, Digital Maps and Charts Series, 55.

Rapprich, V. (2005). The Cinotepeque Range of Central El Salvador: geology, magma origin, and volcanism. Bulletin of Geosciences, 80(4), 277-286. 
Rapprich, V., Erban, V., Farova, K., Kopackova, V., Bellon, H. and Hernandez, W. (2010). Volcanic history of the Conchagua Peninsula (Eastern El Salvador). Journal of Geosciences, 55, 95-112.

Rotolo, S. G. and Castorina, F. (1998). Transition from mildly-tholeiitic to calc-alkaline suite: the case of Chichontepec Volcanic Centre, El Salvador, Central America. Journal of Volcanology and Geothermal Research, 86, 117-136.

Sapper, K., 1897: Über die räumliche anordnung der Mittelamerikanischen vulkane. $Z$. Deut. Geol. Ges., 49, 672-682.

Sofield, D., 2004: Eruptive history and volcanic hazards of volcán San Salvador. In W. I. Rose, J. J. Bommer, D. L. López, M. J. Carr and J. J. Major (eds), Natural hazards in El Salvador (pp. 147-158). Geological Society of America Special Paper 375.

van Wyk de Vries, B., Grosse, P. and Alvarado, G.E. (2007). Chapter 4: volcanism and volcanic landforms. In J. Bundschuh and G. Alvarado (eds), Central America: geology, resources and hazards (pp. 123-154). Netherlands: Balkema.
Walker, J. A., Singer, B. S., Jicha, B. R., Cameron, B. I., Carr, M. J. and Olney, J. L. (2011). Monogenetic, behind-the-front volcanism in Southeastern Guatemala and Western El Salvador: ${ }^{40} \mathrm{Ar} /{ }^{39} \mathrm{Ar}$ ages and tectonic implications. Lithos, 123, 243-253. Doi:10.1016/j.lithos.2010.09.016

Weber, H. S., Wiesemann, G. and Wittekindt, H. (1974). Mapa geológico general de la República de El Salvador 1: 500000 / geologische übersichtskarte der Republik El Salvador 1:500 000. Hannover.

Wiesemann G. (1975). Remarks on the geologic structure of the republic of el salvador, central america. Mitt. Geol.Paläont. Inst. Univ. Hamburg, 44, 557-574.

Williams, H., McBirney, A. R. and Dengo, G. (1964). Geological reconnaissance of Southeastern Guatemala. University of California Publications in Geological Sciences, 50, 1-57.

Williams, H., and Meyer-Abich, H. 1955: Volcanism in the Southern Part of El Salvador. University of California Publications in Geological Sciences, 32, 1-64. 
